\title{
New Disease Reports \\ First report of chilli anthracnose caused by Colletotrichum karstii in India
}

T.J. Saini ${ }^{1}$, S.G. Gupta ${ }^{2}$, B.R. Char ${ }^{1}$, U.B. Zehr ${ }^{1}$ and R. Anandalakshmi ${ }^{1}$

${ }^{1}$ Mahyco Research Centre, Dawalwadi, Jalna-431203, Maharashtra, India; ${ }^{2}$ Government Institute of Forensic Science, Dr. Babasaheb Ambedkar Marathwada University, Aurangabad-431004, Maharashtra, India

*E-mail: tejbhan.saini@mahyco.com

Received: 13 Jul 2016. Published: 08 Aug 2016. Keywords: Capsicum annum

Chilli, Capsicum annum, is an annual herbaceous vegetable and spice grown in almost all the states of India. Anthracnose (fruit rot) of chilli caused by Colletotrichum species results in both pre- and post-harvest fruit decay with yield losses of up to 50\% (Pakdeevaraporn et al., 2005). The different species of Colletotrichum causing chilli anthracnose reported from India include: Colletotrichum acutatum, C. capsici, C. coccodes, C. dematium, $C$. gloeosporioides and C. siamense. In August 2014, chilli fruits showing typical anthracnose symptoms of sunken necrotic tissues with concentric brown black rings of acervuli were obtained from a farmer's field in Jalna, Maharashtra, India.

Small pieces of necrotic tissue were examined under a microscope and spores inoculated on potato dextrose agar (PDA) containing $50 \mathrm{mg} / \mathrm{l}$ streptomycin sulphate. The plates were incubated at $28^{\circ} \mathrm{C}$ for 5 to 7 days and a pure culture of the Colletotrichum isolate was obtained by subculturing on fresh PDA plates. The colonies had white aerial mycelia with an orange conidial mass (Fig. 1). The colour of the colony on the reverse side was light orange. The mycelial growth rate on the PDA plate at $28^{\circ} \mathrm{C}$ and a $16 / 8 \mathrm{~h} \mathrm{light/dark}$ cycle respectively, was $11 \mathrm{~mm}$ per day. Conidia were single celled, cylindrical with rounded base and apex. Mean length and width of conidia was $13.11 \pm 1.22 \mu \mathrm{m}$ and $6.2 \pm 0.34 \mu \mathrm{m}$, respectively (Fig. 2).

Molecular characterization of the Colletotrichum isolate was based on ITS rDNA and partial $\beta$-tubulin gene sequence comparisons. PCR amplification was done using the universal primer pair ITS $4 / 5$ (ITS region of the nuclear ITS1-5.8S - ITS2 rDNA; White et al., 1990) and $\beta$-tubulin gene Bt2a/b primers (Glass et al., 1995). Both sequences were deposited in GenBank (Accession Nos. KX492583 and KX492584, respectively) and aligned with published sequences using MEGA version 6.0 (Tamura et al., 2013), and phylogenetic analysis was done (Fig. 3). Blast searches in the NCBI database revealed that the ITS and $\beta$-tubulin gene sequences had $98 \%$ and 99\% identity to Colletotrichum karstii (KT284369 and KC293650, respectively) confirming that the isolate obtained from infected chilli is $C$. karstii.

To confirm pathogenicity, chilli fruits and seedlings were wounded with a sterile syringe and inoculated with $10 \mu$ of a conidial suspension (c. $10^{5}$ conidia/ml). Sterile water was used as a control. Inoculated fruits and seedlings were kept in a chamber at $28^{\circ} \mathrm{C}$ with $90 \%$ humidity. After seven days typical anthracnose symptoms were observed on chilli fruits and leaves (Fig. 4). This demonstrated that $C$. karstii re-isolated from symptomatic chilli fruits was able to cause anthracnose, thereby fulfilling Koch's postulates.

Colletotrichum karstii as a causal agent of chilli anthracnose has been reported in Brazil (Lima et al., 2013) and China (Wang et al., 2016). To our knowledge, this is the first report of chilli anthracnose caused by $C$. karstii in India.

\section{References}

Glass NL, Donaldson GC, 1995. Development of primer sets designed for use with the PCR to amplify conserved genes from filamentous ascomycetes. Applied and Environmental Microbiology 61, 1323-1330.

Lima NB, Marques MW, Michereff SJ, Morais MA, Barbosa MAG, Camara MPS, 2013. First report of mango anthracnose caused by Colletotrichum karstii in Brazil. Plant Disease 97, 1248. http://dx.doi.org/10.1094/PDIS-01-13-0002-PDN

Pakdeevaraporn P, Wasee S, Taylor PWJ, Mongkolporn O, 2005. Inheritance of resistance to anthracnose caused by Colletotrichum capsici in Capsicum. Plant Breeding 124, 206-208.

http://dx.doi.org/10.1111/j.1439-0523.2004.01065.x

Wang J, Ai CX, Yu XM, An M, Sun S, Gao R, 2016. First report of Colletotrichum karstii causing anthracnose on persimmon leaves in China. Plant Disease 100, 532. http://dx.doi.org/10.1094/PDIS-07-15-0787-PDN

White TJ, Bruns T, Lee S, Taylor J, 1990. Amplification and direct sequencing of fungal ribosomal RNA genes for phylogenetics. In: Innis MA, Gelfand DH, Sninsky JJ, White TJ eds. PCR Protocols - A Guide to Methods and Applications. London, UK, Academic Press, 315-322.

Tamura K, Stecher G, Peterson D, Filipski A, Kumar S, 2013. MEGA6: Molecular Evolutionary Genetics Analysis version 6.0. Molecular Biology and Evolution 30, 2725-2729. http://dx.doi.org/10.1093/molbev/mst197

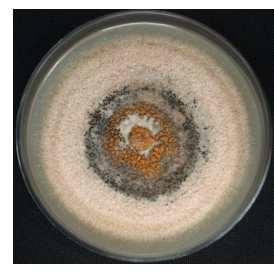

Figure 1

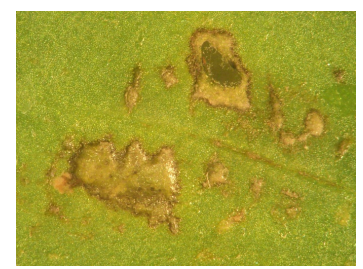

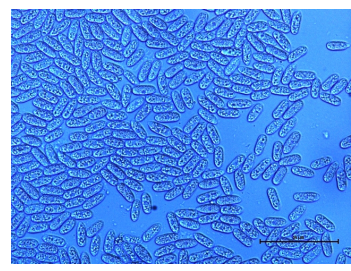

Figure 2

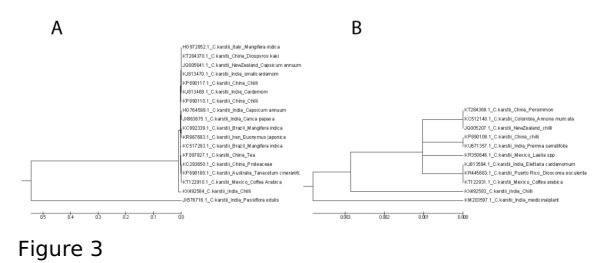

Figure 3

Figure 4

To cite this report: Saini TJ, Gupta SG, Char BR, Zehr UB, Anandalakshmi R, 2016. First report of chilli anthracnose caused by Colletotrichum karstii in India. New Disease Reports 34, 6. http://dx.doi.org/10.5197/j.2044-0588.2016.034.006

(c) 2016 The Authors

This report was published on-line at www.ndrs.org.uk where high quality versions of the figures can be found. 